IZA DP No. 8844

The Impact of Immigrants on Public Finances:

A Forecast Analysis for Denmark

Marianne Frank Hansen

Marie Louise Schultz-Nielsen

Torben Tranæs

February 2015 


\title{
The Impact of Immigrants on Public Finances: A Forecast Analysis for Denmark
}

\author{
Marianne Frank Hansen \\ Danish Rational Economic Agents Model (DREAM) \\ Marie Louise Schultz-Nielsen \\ Rockwool Foundation Research Unit and IZA \\ Torben Tranæs \\ Rockwool Foundation Research Unit and IZA
}

\author{
Discussion Paper No. 8844 \\ February 2015
}

\author{
IZA \\ P.O. Box 7240 \\ 53072 Bonn \\ Germany \\ Phone: +49-228-3894-0 \\ Fax: +49-228-3894-180 \\ E-mail: iza@iza.org
}

\begin{abstract}
Any opinions expressed here are those of the author(s) and not those of IZA. Research published in this series may include views on policy, but the institute itself takes no institutional policy positions. The IZA research network is committed to the IZA Guiding Principles of Research Integrity.

The Institute for the Study of Labor (IZA) in Bonn is a local and virtual international research center and a place of communication between science, politics and business. IZA is an independent nonprofit organization supported by Deutsche Post Foundation. The center is associated with the University of Bonn and offers a stimulating research environment through its international network, workshops and conferences, data service, project support, research visits and doctoral program. IZA engages in (i) original and internationally competitive research in all fields of labor economics, (ii) development of policy concepts, and (iii) dissemination of research results and concepts to the interested public.
\end{abstract}

IZA Discussion Papers often represent preliminary work and are circulated to encourage discussion. Citation of such a paper should account for its provisional character. A revised version may be available directly from the author. 
IZA Discussion Paper No. 8844

February 2015

\title{
ABSTRACT
}

\section{The Impact of Immigrants on Public Finances: A Forecast Analysis for Denmark}

\begin{abstract}
All over Europe, ageing populations threaten nations' financial sustainability. In this paper we examine the potential of immigration to strengthen financial sustainability. We look at a particularly challenging case, namely that of Denmark, which has extensive tax-financed welfare programmes that provide a high social safety net. The analysis is based on a forecast for the entire Danish economy made using a dynamic computable general equilibrium model with overlapping generations. Net contributions to the public purse are presented both as cross-sectional figures for a long time horizon and as average individual life-cycle contributions. The main conclusion is that immigrants from richer countries have a positive fiscal impact, while immigrants from poorer countries have a large negative one. The negative effect is caused by both a weak labour market performance and early retirement in combination with the universal Danish welfare schemes.
\end{abstract}

JEL Classification: F22, E62, J61

Keywords: immigration, sustainable fiscal policy, welfare benefits

Corresponding author:

Marie Louise Schultz-Nielsen

The Rockwool Foundation Research Unit

Sølvgade 10, 2 tv.

DK-1307 Copenhagen K

Denmark

E-mail: mls@rff.dk 


\section{Introduction}

In the debate concerning the challenges presented to a welfare society by an ageing population, immigration is often mentioned as one of the possible solutions to secure income for the public purse. But is this in fact a solution? Is it sensible from an economic point of view to increase immigration - for the economy in general, and for the public finances in particular? Moreover, is the answer to this question the same irrespective of the type of welfare society under consideration? The focus in this paper will be on the effect of immigration on public finances, because the effects on the economy as a whole are likely to be small for the average citizen, being mainly distributional in character (Borjas, 1990). We examine specifically a particularly challenging case, namely that of Denmark - a society with extensive tax-financed welfare programmes that provide a high social safety net.

The fact that a high social safety net has been, and still is, an important priority of Denmark's welfare spending not only makes the welfare programmes expensive, it also makes it especially difficult for the country to make immigration a contributory factor to financial sustainability, in particular immigration from poor countries. On the one hand, the expensive income-tax financed welfare programmes require a high population average employment rate for the operation to be financially sustainable; and one the other hand, the high social safety net induces high effective minimum wages that make it difficult for newcomers to get into employment unless they are very productive to begin with, which many immigrants from poor countries tend not to be.

Thus, for immigration to improve financial sustainability in a high-spending welfare country, the immigrants' skills need to be both high and compatible with the requirements of the labour market. Unfortunately, the mix of immigrants coming to Denmark has on average been weak with respect to labour market qualifications. This was particularly the case up until the late 1990s, and as a result immigration resulted in a deficit to the public purse around the year 2000 which was solely attributable to immigrants from poor countries. At around the same time, Germany was managing to attract both better educated and more experienced immigrants than Denmark (Tranæs and Zimmerman, 2004). ${ }^{1}$ (To indicate rich and poor countries in this paper, we use Statistics Denmark's categories of Western and non-Western countries. The non-Western countries are mainly poor countries, being non-OECD countries or low-income OECD countries plus a few richer Asian countries, as detailed in section 2)

The main reason for the unfavourable mix of immigrants to Denmark in terms of their employability at the time mentioned was the fact that Denmark received relatively few migrants who came to the country for work and study purposes. Only $25 \%$ on the residence permits issued to people from nonWestern countries around 2000 were for employment or education purposes, the remaining $75 \%$ being to refugees or family reunification immigrants. A new immigration policy introduced around 2000 changed this dramatically, so that by 2008 the fraction of residence permits granted for

\footnotetext{
${ }^{1}$ This is not due to a particular mix of nationalities among the immigrants. Compared to the immigrants to Denmark, the immigrants to Germany were better educated and had longer work experience for each sending country.
} 
employment and education purposes had reached $80 \%$, and in addition the total number of such permits granted had increased. This trend in residence permits seems to have been associated with an upward trend in employment rates among non-Western immigrants in Denmark that peaked in 2008 (Tranæs, 2012). The gap between the employment rates of native Danes and non-Western immigrants dropped from 33 to 23 percentage points between 2000 and 2008, and consequently, the contribution from immigration to the public finances improved significantly over that period. Nevertheless, in 2008 the employment rate for non-Western immigrants was still 56\%, compared to $79 \%$ for natives, and immigration from non-Western countries still created a deficit even under the assumption that the cost of providing fixed public goods to immigrants was zero, as shown by Gerdes et. al. (2011). ${ }^{2}$ With the coming of the recession the improvement in employment integration came to a halt, and in the years 2010 to 2013 it remained constant at a somewhat lower level than previously, with an employment rate gap between natives and non-Western immigrants of 26 percentage points.

Thus, 2008 represented an all-time high for immigrant employment in Denmark; the new policy had been in place for a decade, and the economy was booming. Since in this paper we study the potential contribution of immigration, 2008 is an obvious year on which to base expectations in order to answer the question, to what extent might immigration contribute to fiscal sustainability?

We are interested in the total net effect - including indirect effects from demographic changes, from educational attainment, from the labour market, from the marriage market, etc. - and for consistency, we make a forecast for the entire Danish economy. We look both at cross-sectional situations and at the life-time fiscal contribution of the average individual. The cross-sectional views are constructed for the recent past, when the second generation of immigrants were young and the first generation on average of middle age, and for a time some way in the future when the young will have grown into adulthood and the adults started to retire. The average life-cycle perspective is calculated in order to control for the influence of demographic compositional effects.

Specifically, we ask to what extent the various population groups in Denmark contribute to public finances today, and how much we can expect the immigrant groups to contribute if we look forward in time by half a generation, to the year 2050. The calculations were carried out using the Danish Rational Economic Agents Model (DREAM), a dynamic computable general equilibrium model with overlapping generations. The model encompasses projections of population growth, educational attainment, demographic characteristics, education, and country of origin.

We have performed the forecast based on the economic structures of 2008 and assuming a continuation of these, except that we have taken into account future changes that will be a consequence of reforms already approved by parliament up until $2012 .{ }^{3}$ We predict how the net contributions to the public purse from people of Danish origin and from immigrants and second-

\footnotetext{
2 If refugees are excluded from the calculation, the overall contribution from all immigrants - from both poor and rich countries - was a small positive amount in 2008.

${ }^{3}$ For the years up until 2020, the model is fitted to reproduce key macroeconomic figures from the most recent official forecast by the Ministry of Finance.
} 
generation immigrants of both Western and non-Western origins are expected to change over time. With the type of model used, such a forecast can also predict the total budget for the public sector year by year, which we will summarise and present as sustainability indicators (SI) measured in percentages of GDP or as average annual budget surpluses in Euro.

In all the forecasts, public transfers related to individuals (unemployment benefit, child benefit, taxes, etc.) and all publicly-provided services linked to individuals (education, visits to the doctor, etc.) are assigned to each population group according to actual use. With regard to the remaining public expenditures, i.e. the costs of fixed public goods (armed forces, construction of roads and bridges, central administration, etc.), computations are made both where these are allocated equally across all individuals, implying that immigrants are assigned the average cost of public goods, and where immigrants are assigned the marginal cost of providing fixed public goods to immigrants, which is assumed to be zero.

We focus on the following three computations.

First, we compute the annual net contributions to the public sector from each population group from 2014 to 2050 with the costs of fixed public goods being allocated equally across all individuals.

Second, under the same assumption regarding fixed public goods, we compute the present values of life-time net contributions for the 2013 cohort as a whole and separately for each of the population groups studied. We control for both the number of years of residence in the country and for the particular period of life when individuals resided in Denmark. These computations are also used to study the difference in terms of net contributions between refugees and other non-Western immigrants.

The results up until this point, with the costs of fixed public goods allocated equally to both natives and immigrants, suggest that immigration from poor countries (non-Western countries) represents a net cost to the public purse, while immigration from richer countries (Western countries) generates a net contribution. However, a small change in the population size does not change the cost of providing fixed public goods. Consequently, the marginal net benefit of immigration is obtained by setting the cost of providing fixed public goods to immigrants to zero. For Western immigrants the marginal net benefit to the public purse of immigration is positive, because this was the case even when the immigrants were carrying their full share of the cost of fixed public goods. But what about the marginal benefit to the public purse of immigration from poor countries? We compute this by changing the yearly inflow of immigrants while keeping the total costs of fixed public goods unchanged, and then examine how this would affect public finances, measured in terms of fiscal sustainability. The result found is that the marginal fiscal impact of immigration from poor countries is negative.

This last computation of the marginal benefit of immigration is particularly relevant for policy, because the political question concerning immigration is (always) the question of whether to have more immigration or less immigration, not whether to have immigration or no immigration at all. 
By considering both the cases where immigrants are counted as paying the average per capita cost of fixed public goods and only the marginal cost of these goods (i.e. zero), we are following Dustmann and Frattini (2013). Although we arrive at the same overall picture for Denmark as they do for the UK - that immigrants from richer countries reduce the fiscal burden on the natives of the country, while immigrants from poorer countries perform worse in terms of their contribution than those from richer countries - we arrive at a less optimistic picture with regard to immigration from non-Western countries than Dustmann and Frattini do for non-EEA immigrants. They find that at least the recently arrived non-EEA immigrants to the UK make a net contribution to the public purse; we consistently find negative net contributions in the case of non-Western immigrants to Denmark. The employment rates for non-EEA citizens in Denmark and the UK are not that different, and although the employment rate for non-Western immigrants is lower than for the, on average, somewhat betterintegrated non-EEA immigrants, this suggests that the difference in the results is mainly linked to the general differences in the generosity of the two countries' welfare systems. This view is supported by the findings in Ruist (2014). Studying the fiscal implication of immigration from the new EU countries to Sweden, he finds zero or only small positive fiscal effects, suggesting that the effects of non-EU immigration to Sweden are negative, as the employment rate for these immigrants is much lower than that for EU immigrants. Altogether this suggests that the mix of immigrants is important for their fiscal impact, and that for certain immigrant groups, welfare societies like those of Scandinavia face a considerable structural challenge with respect to achieving a net surplus for the public purse as a result of immigration.

The methodical approach applied in this study is related to that used by Schou (2006), who utilises DREAM to assess the consequences of increasing the future inflow of immigration by 5,400 persons yearly. He finds that this increase would worsen the Danish fiscal sustainability problem by $0.14 \%$ of GDP annually, or by $0.49 \%$ if all the immigrants were from less developed countries and were considered to be paying the average per capita cost of fixed public goods. Schou does not compute the marginal costs of immigration, and immigrant employment was significantly lower in his base year of 2004 than in 2008. Other analyses calculating the net transfers based on cross-sectional data for first- and second-generation immigrants of Western and non-Western origin confirm this picture; see Wadensjö $(2000,2007)$ and Gerdes et. al. (2011). Wadensjö and Gerdes (2004) also show that the net transfers per person are larger for non-Western immigrants in Denmark than in Germany; as in the similar case of the UK (Dustmann and Frattini, 2013), this may be explained by differences in the mix of immigrant populations and the welfare systems of the countries, as discussed in Hinte and Zimmermann (2014).

The present study goes further than previous studies of the fiscal effects of immigration by considering life-cycle estimates of the impact of immigration, by forecasting from the employment peak year 2008, and by considering the marginal cost of immigration. Finally, the paper also reveals how much of the net cost of non-Western immigration is explained by the fact that many of these immigrants are refugees rather than ordinary immigrants. All this is facilitated by using a computable general equilibrium model built on rich register data which include information about both first- and second-generation immigrants. 
Another advantage of working with this model is that it ensures that indirect effects are also included in the calculations. For instance, the tax revenue from income - for instance, profit income - earned by natives because of immigration is included in our computation, thanks to the general equilibrium properties of the model used.

This paper is organised as follows. Section 2 presents the data and the model. In Section 3 we present the baseline total net contributions year by year for the different population groups. Section 4 contains the life-cycle computations, while Section 5 discusses financial sustainability under different possible immigration policies. Finally, Section 6 concludes and addresses the overriding question of the extent to which immigration from various parts of the world can contribute to solving the financing challenges faced by countries such as Denmark as a result of an ageing population.

\section{Data and methods}

The following provides a brief introduction to the Danish Rational Economic Agents Model (DREAM) and to the assumptions on which the calculations are based.

\subsection{General description of the model}

Our results are based on the DREAM projections of 2013 (DREAM, 2013b). The model estimates longterm economic activities and sustainability of economic policy on the basis of projections of the demographic composition, level of education, and labour market participation of the Danish population. In particular, it is frequently used to address the question of whether the present fiscal policy or specific changes to it are sustainable. The DREAM modelling system consists of a number of nested sub-models which generate input to a Computable General Equilibrium model (CGE model).

The first sub-model consists of a population projection, which is based on assumptions concerning fertility rates, mortality rates, and inward and outward migration (DREAM, 2013a). This projection is made in collaboration with Statistics Denmark, and constitutes the official national population projection for Denmark.

The next sub-model is concerned with determining the future education behaviour of the population. Using gender-, age- and origin-specific probabilities concerning respectively the commencement, continuation, drop-out-rate, and completion of study programmes, the shares of the future population who will have various education levels are calculated. Then, using gender-, age-, originand education-specific participation rates, the third sub-model assigns the future population to numerous socioeconomic categories within and outside the labour force. Hence, the output from the third-sub-model establishes the future proportions of the population within and outside the labour force, and this serves as the primary input in the CGE model.

On the basis of the information from the system of sub-models, the model can be used to forecast several components of the Danish economy. The model consists, first, of households that supply labour, demand goods and services, accumulate wealth (savings and pensions), and pay taxes to the public sector. The production sector demands labour, produces goods, invests in capital, issues stocks, pays taxes and wages, and receives subsidies. Finally, the public sector requires financing 
from taxation, provides public services, pays transfers to households, and pays interest on public debts. By taking into account expected future public revenues and spending, the model can be used to assess whether or not a given fiscal policy is sustainable.

In the DREAM projections of 2013, the size of the shortfall in the sustainability of fiscal policy is calculated as being $0.04 \%$ of GDP, equivalent to EUR -0.09 billion. This means that the public sector will have a (small) financing need of EUR 0.09 billion every year in the future - which in turn means that future revenue will be virtually sufficient to cover future costs. This calculation is based on the assumption that the current economic policy regime is continued and that the economic reforms of recent years are implemented as planned. ${ }^{4}$

Participation rates are exogenous in DREAM, and the model is as noted fitted to reproduce key macroeconomic figures until $\mathbf{2 0 2 0}$ from the most recent official forecast by the Ministry of Finance. The projection embodying all of the above is referred to as the baseline scenario.

The exercise we conduct is the following. Supposing that the economy evolves as officially expected, what then will be the net contribution to public finances of the different population groups considered?

\section{Distribution of net contributions according to origins of the contributors}

In order to divide up net contributions to public funds according to the origin of the contributors, all income to the Danish public sector should in principle be categorised according to the contributors' gender, age and origin. The definition of origin used here is in accordance with that used by Statistics Denmark (Danmarks Statistik, 2013), which in outline is as follows:

Immigrants were born outside Denmark. Neither of their parents was a Danish national born in Denmark.

Second-generation immigrants ${ }^{5}$ were born in Denmark. Neither of their parents was a Danish national born in Denmark.

All individuals, regardless of their place of birth, who have at least one parent who is a Danish national born in Denmark, are defined as natives.

In the following, we distinguish between Western and non-Western countries. Western countries are the 28 countries of the European Union plus Andorra, Iceland, Lichtenstein, Monaco, Norway, San

\footnotetext{
${ }^{4}$ For a more detailed description of this economic forecast, see DREAM (2013b).

${ }^{5}$ In principle, all descendants of immigrants are included in this group if neither of their parents is a Danish national born in Denmark. In practice, this group currently consists almost entirely of second-generation immigrants and includes only a few third-generation immigrants.
} 
Marino, Switzerland, the Vatican State, Canada, the USA, Australia and New Zealand. All other countries are categorised as non-Western countries.

Calculations made using DREAM are carried out as follows. First, the calculation of the overall economic projection is performed, and then the public sector budget is broken down according to the gender, age, and origin of individuals. In practice, dividing up public income and expenditure demands the use of a set of distribution keys. The key to be used depends on which type of income or expenditure is involved, and on the extent to which the item in the budget can be linked to a specific population group.

Some budget items are distributed directly by definition, while others have to be distributed subsequently. Overall, the following six principles describe the way budget items are distributed by population groups:

Group 1 consists of items which are distributed directly by DREAM according to gender, age and population group. This group is composed of the many items which are linked to individuals by the definitions in microdata, such as wages, labour market contribution tax, student grants, old-age pensions and disability pensions.

Group 2 is made up of items which are attributed only according to gender and age in DREAM. These items are subsequently distributed according to country of origin by relating them to the gender and age distributions of the origin groups. They include, for example, inheritance tax.

Group 3 consists of items which are attributed only according to age in DREAM. In order to divide up these items according to gender and origin, one of the following is used as a distribution key:

a) Disposable income (excluding interest). Examples of items attributed in this way are VAT and other indirect taxes.

b) The proportion of the adult population (above the age of 16) made up by the population group. These items include, for example, voluntary contributions to benefit schemes and capital transfers from the public sector.

Group 4 consists of items which are not initially distributed. These are distributed according to gender, age and origin through the use of the following distribution keys:

a) Share of the adult population (above the age of 16) made up by the population group in question. This distribution key is used for items which are only given to or required from the adult population, such as corporate tax.

b) Share of the entire population made up by the population group in question. This distribution key is used for items that concern the entire population. In particular, it includes collective public services, such as central administration, defence, and road construction. 
Table 1 shows an overview of the distribution principles for all items of income and expenditure. Where the budget item consists of several sub-items that are distributed according to different principles, both principles are indicated.

\subsection{The composition of the net contributions by population groups, 2014}

The result of dividing up net contributions according to origin is shown below. The calculations are based on the long-term projections by DREAM of 2013, which tracks the Finance Ministry's projected primary budget balance until the year of 2020. In order to avoid assigning too much weight to major fluctuations in the primary balance in certain years (for example, because of changes in the regulations on lump sum pension payments), it was decided to calculate an average for the years 2013-15, this average being referred to hereafter as 2014. Subsequently, results are shown for 2050. These two points in time were chosen in part to show how income, expenditure and net contributions are distributed across groups, and in part to show changes in net contributions over time. 
Table 1. Distribution principles for items of income and expenditure

\begin{tabular}{|c|c|c|c|c|c|c|}
\hline Distribution principle & 1 & 2 & $3 a$ & $3 b$ & $4 a$ & $4 b$ \\
\hline \multicolumn{7}{|l|}{ Income from: } \\
\hline VAT (from households) & & & $x$ & & & \\
\hline Other indirect taxes & & & $x$ & & & \\
\hline Tax deducted at income source & $x$ & & $x$ & & & \\
\hline \multicolumn{7}{|l|}{ Other direct taxes } \\
\hline Labour market contribution tax & $x$ & & & & & \\
\hline Other personal taxes & & $\mathrm{x}$ & & & & \\
\hline Motor vehicle tax (from households) & & & $x$ & & & \\
\hline Corporation tax, real interest rate tax & & & & & $x$ & \\
\hline \multicolumn{7}{|l|}{ Other income } \\
\hline Interest, dividends, etc. & & & & & $x$ & \\
\hline Lump sum correction & & & & $x$ & & \\
\hline Gross remaining income & & & & & $x$ & \\
\hline \multicolumn{7}{|l|}{ Contributions to social insurance programmes } \\
\hline - Obligatory & $x$ & & & $x$ & $x$ & \\
\hline - Voluntary & & & & $x$ & & \\
\hline - Imputed & & & & & $x$ & \\
\hline Other transfers & & & & $x$ & $x$ & \\
\hline Capital taxes (inheritance tax) & & $x$ & & & & \\
\hline \multicolumn{7}{|l|}{ Capital transfers } \\
\hline - from abroad & & & & & $x$ & \\
\hline - $\quad$ from the private sector & & & & $x$ & & \\
\hline \multicolumn{7}{|l|}{ Expenditure on: } \\
\hline $\begin{array}{l}\text { Income replacement payments (pension, early } \\
\text { retirement benefit, student maintenance } \\
\text { grants, etc.) }\end{array}$ & $x$ & & & & & \\
\hline Payments not related to income replacement & $x$ & $x$ & & & & \\
\hline $\begin{array}{l}\text { Public expenditure on individuals (education, } \\
\text { health, social security) }\end{array}$ & $x$ & & & & & \\
\hline Public expenditure on collective services & & & & & & $\mathrm{x}$ \\
\hline Other expenditure & & & & $x$ & $x$ & $\mathrm{x}$ \\
\hline
\end{tabular}


Table 2 shows how the expected annual public revenues and expenditures for 2014 are distributed in DREAM by country of origin when the principles described above are applied. The calculations are shown in 2013 values, where 100.00 Euro is equal to 746.80 Danish kroner.

Table 2. Predicted annual public revenue and expenditure, distributed according to origin, 2014. EUR billions (2013 values)

\begin{tabular}{|c|c|c|c|c|c|c|}
\hline & Natives & $\begin{array}{l}\text { Western } \\
\text { immigrants }\end{array}$ & $\begin{array}{l}\text { Western } \\
\text { second- } \\
\text { generation } \\
\text { immigrants }\end{array}$ & $\begin{array}{l}\text { Non- } \\
\text { Western } \\
\text { immigrants }\end{array}$ & $\begin{array}{l}\text { Non- } \\
\text { Western } \\
\text { second- } \\
\text { generation } \\
\text { immigrants }\end{array}$ & Total \\
\hline \multicolumn{7}{|l|}{ Income from: } \\
\hline Taxes deducted at source & 40.40 & 1.29 & 0.07 & 1.43 & 0.12 & 43.30 \\
\hline Other direct taxes & 21.60 & 0.93 & 0.04 & 1.09 & 0.20 & 23.89 \\
\hline Other indirect taxes & 25.26 & 1.17 & 0.05 & 1.54 & 0.32 & 28.36 \\
\hline Other types of income & 11.77 & 0.56 & 0.03 & 0.80 & 0.13 & 13.30 \\
\hline VAT from households & 11.52 & 0.50 & 0.03 & 0.60 & 0.16 & 12.82 \\
\hline Expenditure on: & 0.00 & 0.00 & 0.00 & 0.00 & 0.00 & 0.00 \\
\hline $\begin{array}{l}\text { Labour market activation } \\
\text { programmes }\end{array}$ & -0.86 & -0.04 & 0.00 & -0.19 & -0.03 & -1.13 \\
\hline Unemployment benefit & -1.66 & -0.09 & 0.00 & -0.20 & -0.01 & -1.97 \\
\hline Early retirement benefit & -2.12 & -0.04 & 0.00 & -0.03 & 0.00 & -2.21 \\
\hline Old age pension & -13.33 & -0.34 & -0.01 & -0.24 & 0.00 & -13.93 \\
\hline Parental leave & -1.02 & -0.05 & 0.00 & -0.07 & -0.01 & -1.18 \\
\hline Disability benefit & -3.71 & -0.09 & -0.01 & -0.60 & -0.01 & -4.42 \\
\hline $\begin{array}{l}\text { Payments not related to } \\
\text { income replacement }\end{array}$ & -8.80 & -0.21 & -0.04 & -0.36 & -0.28 & -9.71 \\
\hline \multicolumn{7}{|l|}{$\begin{array}{l}\text { Public services for } \\
\text { individuals }\end{array}$} \\
\hline - care & -12.79 & -0.36 & -0.09 & -0.51 & -0.44 & -14.20 \\
\hline - health & -17.85 & -0.51 & -0.05 & -0.72 & -0.20 & -19.35 \\
\hline - education and training & -11.12 & -0.28 & -0.07 & -0.46 & -0.74 & -12.66 \\
\hline - other & -1.45 & -0.05 & 0.00 & -0.07 & -0.04 & -1.62 \\
\hline Social assistance benefit & -0.70 & -0.03 & 0.00 & -0.25 & -0.01 & -1.01 \\
\hline Student maintenance grants & -1.62 & -0.07 & -0.01 & -0.11 & -0.07 & -1.88 \\
\hline Sickness benefit & -1.74 & -0.05 & 0.00 & -0.17 & -0.01 & -1.98 \\
\hline $\begin{array}{l}\text { Collective public } \\
\text { expenditures }\end{array}$ & -16.87 & -0.68 & -0.07 & -0.93 & -0.44 & -18.99 \\
\hline Other expenditures & -17.59 & -0.79 & -0.05 & -1.10 & -0.27 & -19.82 \\
\hline Total net contributions & -2.65 & 0.70 & -0.19 & -0.55 & -1.68 & -4.40 \\
\hline Proportion of the population & $89.0 \%$ & $3.5 \%$ & $0.4 \%$ & $4.9 \%$ & $2.3 \%$ & $100 \%$ \\
\hline
\end{tabular}

Source: DREAM projection of 2013 and own calculations 
As the table shows, taxes deducted at income source (EUR 43 billion) are the single largest item of income for the public purse, and they derive mostly from the taxation of wages, income transfers and pension payments. However, other direct taxes (EUR 24 billion) and other indirect taxes (EUR 28 billion) are also very significant. Other types of income contribute EUR 13 billion, while VAT from households makes up EUR 13 billion. On the outgoing side of the balance sheet, individual services in the areas of health, welfare and education weigh heavily, with sums of EUR 19 billion, EUR 14 billion and EUR 13 billion respectively in 2014. Expenditures on old-age pensions (EUR 14 billion) and collective public spending (EUR 19 billion) are also large items.

Since the natives make up $89 \%$ of the population of Denmark, by far the greatest proportion of state income and expenditure is linked to this group. However, the contributions made by natives in the form of taxes and duties are a little smaller than the public expenditures targeted at this specific group. Hence, in 2014, the total net contribution from all natives will be negative, EUR -2.7 billion. First-generation Western immigrants, in contrast, will make a positive net contribution of EUR 0.7 billion, while second-generation Western immigrants will make a negative net contribution of EUR -0.2 billion. In total, non-natives of Western origin living in Denmark will make a positive net contribution to public funds of EUR 0.5 billion.

The fact that the net contribution is greater for first-generation immigrants than for the second generation is due in particular to the second generation being young, and therefore not yet contributing significantly via tax payments. Two out of three second-generation Western immigrants are under 20 years of age (Danmarks Statistik, 2013), whereas this is only the case for one in three first-generation Western immigrants and natives.

The net contribution is negative for people of non-Western origin as a whole, totalling EUR -2.2 billion. For the first generation the net contribution in 2014 will be EUR -0.55 billion, while for second-generation immigrants it will be EUR -1.7 billion. Here again, the second-generation immigrants are much younger than the first generation, with nine out of ten second-generation nonWestern immigrants being under the age of 30 . Consequently, revenue from taxes is low for this group, while expenditures related to education and care in particular are high.

On the other hand, the fact that net contributions from non-Western immigrants are lower than those from Western immigrants is due to a lower rate of employment among non-Westerners, rather than any difference in age structure between the two immigrant groups. This leads to lower revenue from taxes and higher expenditure on social income transfers.

\subsection{The expected net contribution by 2050}

According to the DREAM projection, what can we expect regarding the distribution of public expenditures and incomes among population groups in the year 2050? The answer can be found in Table 3, where the population is distributed by origin in accordance with the population projection by DREAM and Statistics Denmark. 
Before looking at the forecast for 2050, we describe the assumptions made regarding immigration over the period up until then. Figure 1 shows the expected ethnic composition of the population in Denmark for the period 2013 to 2050.

Figure 1. Population in Denmark distributed according to origin, 2013-2050.

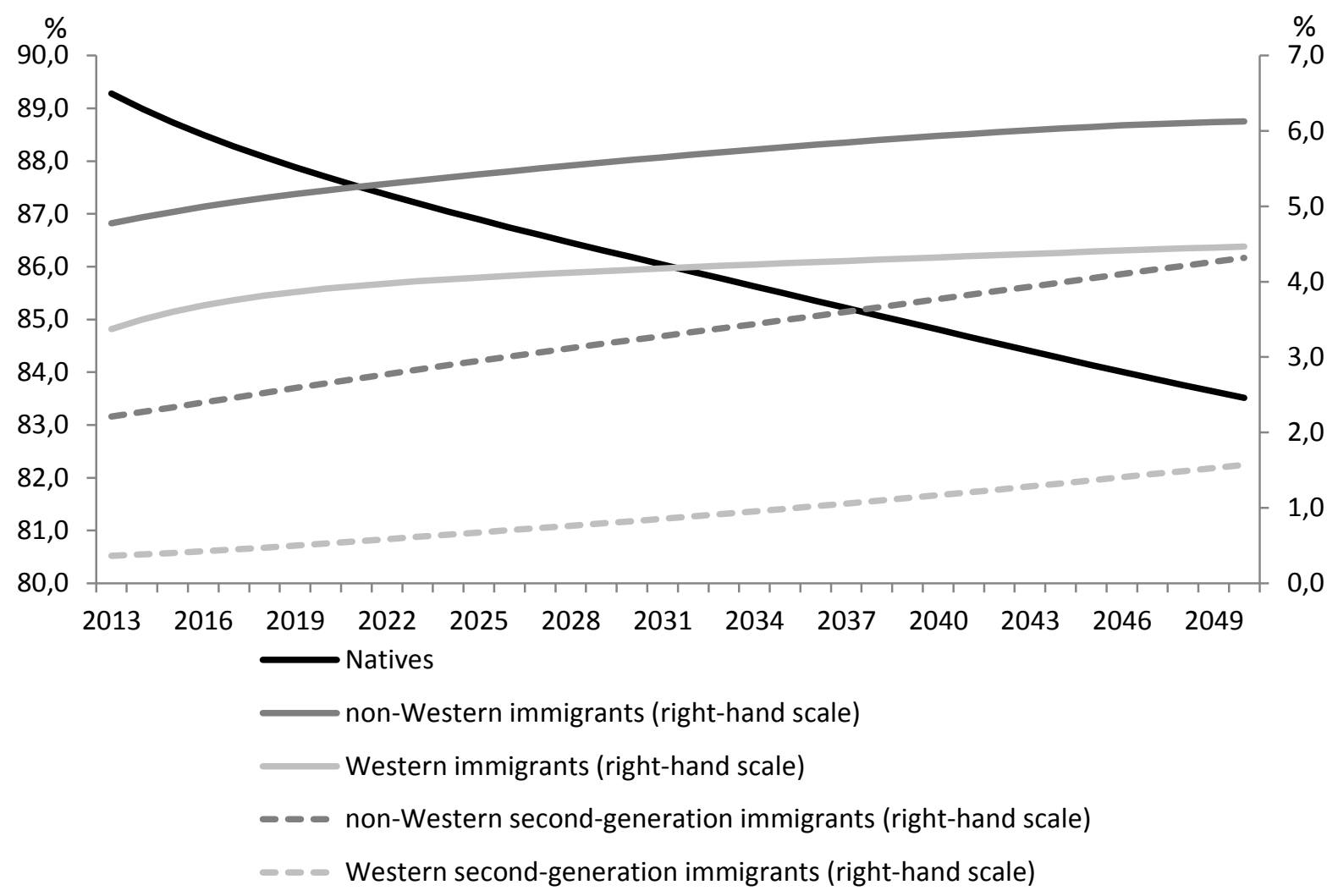

Source: DREAM projection of 2013

It is forecasted that natives will make up $84 \%$ of the total population in 2050 , while Western immigrants and second-generation immigrants will comprise $4.5 \%$ and $1.6 \%$ of the population respectively. Non-Western immigrants and second-generation immigrants will make up $6.1 \%$ and $4.3 \%$ of the population respectively.

As in Table 2, incomes and expenditures are presented in 2013 values in Table 3. The total net contribution to public finances by natives in 2050 is predicted to be EUR -1.8 billion. For firstgeneration Western immigrants it is estimated to be EUR 1.5 billion, with the contribution from second-generation non-Western immigrants being EUR - 0.24 billion - overall, an expected surplus of EUR 1.2 billion from immigrants of Western origin.

The net contribution in 2050 is expected to be negative for people of non-Western origin, totalling EUR -0.8 billion. In contrast to the situation in 2014, the first generation of immigrants will make a large negative net contribution (EUR -1.6 billion), while the second generation contribute a positive sum (EUR 0.8 billion). This development will be largely attributable to changes in the age compositions of the groups. Simplifying a little, we can say that the second-generation non-Western immigrants who were children in 2014 will have grown up by 2050 and be part of the workforce, 
Table 3. Projected public revenues and expenditures, distributed by origin of individuals, 2050. EUR billions (2013 values)

\begin{tabular}{|c|c|c|c|c|}
\hline Natives & $\begin{array}{l}\text { Western } \\
\text { immigrants }\end{array}$ & $\begin{array}{l}\text { Western } \\
\text { second- } \\
\text { generation } \\
\text { immigrants }\end{array}$ & $\begin{array}{l}\text { Non- } \\
\text { Western } \\
\text { immigrants }\end{array}$ & $\begin{array}{ll}\text { Non- } & \text { Total } \\
\text { Western } & \\
\text { second- } & \\
\text { generation } & \\
\text { immigrants } & \end{array}$ \\
\hline
\end{tabular}

\begin{tabular}{|c|c|c|c|c|c|c|}
\hline \multicolumn{7}{|l|}{ Income from: } \\
\hline Taxes deducted at source & 41.98 & 2.16 & 0.42 & 2.52 & 1.96 & 49.05 \\
\hline Other direct taxes & 18.85 & 1.18 & 0.29 & 1.19 & 1.05 & 22.57 \\
\hline Other indirect taxes & 26.70 & 1.68 & 0.43 & 2.20 & 1.33 & 32.33 \\
\hline Other types of income & 10.87 & 0.75 & 0.17 & 1.01 & 0.60 & 13.40 \\
\hline VAT from households & 12.23 & 0.71 & 0.20 & 0.76 & 0.63 & 14.56 \\
\hline \multicolumn{7}{|l|}{ Expenditure on: } \\
\hline $\begin{array}{l}\text { Labour market activation } \\
\text { programmes }\end{array}$ & -0.75 & -0.05 & -0.01 & -0.17 & -0.07 & -1.09 \\
\hline Unemployment benefit & -1.22 & -0.11 & -0.01 & -0.17 & -0.07 & -1.60 \\
\hline Early retirement benefit & -0.35 & -0.01 & 0.00 & -0.01 & 0.00 & -0.40 \\
\hline Old age pension & -12.27 & -0.39 & -0.03 & -0.88 & -0.04 & -13.61 \\
\hline Parental leave & -1.01 & -0.07 & -0.03 & -0.05 & -0.05 & -1.22 \\
\hline Incapacity benefit & -3.59 & -0.16 & -0.04 & -1.06 & -0.15 & -5.00 \\
\hline $\begin{array}{l}\text { Payments not related to } \\
\text { income replacement }\end{array}$ & -5.78 & -0.21 & -0.12 & -0.48 & -0.29 & -6.89 \\
\hline \multicolumn{7}{|l|}{$\begin{array}{l}\text { Public services for } \\
\text { individuals }\end{array}$} \\
\hline - care & -14.36 & -0.54 & -0.28 & -0.87 & -0.63 & -16.68 \\
\hline - health & -23.38 & -0.94 & -0.24 & -1.77 & -0.66 & -26.99 \\
\hline - education and training & -10.61 & -0.28 & -0.31 & -0.40 & -0.66 & -12.24 \\
\hline - other & -1.42 & -0.07 & -0.03 & -0.11 & -0.07 & -1.69 \\
\hline Social assistance benefit & -0.66 & -0.04 & -0.01 & -0.34 & -0.07 & -1.14 \\
\hline Student maintenance grants & -1.54 & -0.07 & -0.05 & -0.07 & -0.11 & -1.88 \\
\hline Sickness benefit & -1.80 & -0.11 & -0.03 & -0.25 & -0.13 & -2.31 \\
\hline $\begin{array}{l}\text { Collective public } \\
\text { expenditures }\end{array}$ & -16.87 & -0.90 & -0.32 & -1.23 & -0.88 & -20.22 \\
\hline Other expenditures & -16.77 & -1.03 & -0.28 & -1.42 & -0.84 & -20.33 \\
\hline Total net contributions & -1.78 & 1.46 & -0.24 & -1.64 & 0.83 & -1.37 \\
\hline Proportion of the population & $83.5 \%$ & $4.5 \%$ & $1.6 \%$ & $6.1 \%$ & $4.3 \%$ & $100 \%$ \\
\hline
\end{tabular}

Source: Special run of DREAM and own calculations 
while their parents will have aged and retired from work. At the same time, however, it is assumed that new non-Western immigrants will have settled in Denmark, and new second-generation immigrants will have been born - factors which will obviously affect the situation. Overall, however, it is expected that only four out of ten second-generation non-Western immigrants will be aged under 30 in 2050, and that, of course, makes a very substantial difference - compared to 2014 when calculating the net contribution from this group.

As the discussion above shows, the calculation of the annual net contribution from each population group defined by origin is heavily dependent on the size of the group in question and on its age composition, as well as on the employment rates. The age composition plays a crucial role because of the Danish universal old-age pension system. In fact, changes in the rate of employment and in the age composition are the main reasons that the net contributions to the public purse from the nonWestern group become smaller over the period, while nevertheless remaining substantial in 2050. Table 4 show that the employment rate for the non-Western group of working age is calculated to increase from $50.3 \%$ in 2014 to $60.1 \%$ in 2050 , while the employment rate for the entire group over 16 years of age only will increase from $47.6 \%$ in 2014 to $50.4 \%$ in 2050 . So the large increase in employment among working-age non-Western immigrant is almost completely offset by more retired people - and both unemployed and retired people receive social benefits. This shows how important the age composition of the population is for net public contributions.

Table 4. Employment rates by origin in basic scenario, 2014 and 2050

\begin{tabular}{lcclclll}
\hline & Natives & $\begin{array}{l}\text { Western } \\
\text { immigrants }\end{array}$ & $\begin{array}{l}\text { Western } \\
\text { second- } \\
\text { generation } \\
\text { immigrants }\end{array}$ & $\begin{array}{l}\text { All } \\
\text { Western }\end{array}$ & $\begin{array}{l}\text { Non- } \\
\text { Western } \\
\text { immigrants }\end{array}$ & $\begin{array}{l}\text { Non- } \\
\text { Western } \\
\text { second- } \\
\text { generation } \\
\text { immigrants }\end{array}$ & $\begin{array}{l}\text { All non- } \\
\text { Western }\end{array}$ \\
\hline Age 17+: & & & & & & & \\
\hline 2014 & 58.4 & 53.5 & 60.4 & 53.9 & 45.6 & 58.2 & 47.6 \\
\hline 2050 & 60.5 & 57.7 & 67.6 & 59.6 & 38.2 & 72.5 & 50.4 \\
\hline Aged 17-64: & & & & & & & \\
\hline 2014 & 74.1 & 60.6 & 66.7 & 61.0 & 48.7 & 58.3 & 50.3 \\
\hline 2050 & 78.3 & 65.7 & 69.5 & 66.6 & 50.0 & 73.3 & 60.1 \\
\hline
\end{tabular}

Source: DREAM projection of 2013

In order to see whether the negative net contributions are due purely to inauspicious demographic developments or whether weak labour market performance is also a major contributing factor we consider the financial sustainability of the average member of the population in the next section.

\section{Present value of the net life-time contributions of the 2013 cohort}

This section calculates the net contributions to public finances made over the course of a lifetime. In other words, we calculate what a single person from a specific population group can be expected to contribute to public funds on average in each year of the part of that person's life which was spent in 
Denmark. By studying the fiscal impact in this way we control for the different sizes of the population groups, and for the fact that the net annual contribution varies over the course of a lifetime.

The calculation is based on people born in 2013, henceforth referred to as 'the 2013 cohort'. Tracking a cohort and calculating its average net contributions over the course of a lifetime has the advantage that the calculation does not depend on the age composition and size of the population at a given point in time. This facilitates comparison across population groups.

Below we first construct the 2013 cohort. Then we assign age-dependent public revenues and expenditures to each population group, and finally, by taking into account the number of years of residence in Denmark, the average present-value net contribution can be computed for each population group. The contribution is measured in Euro per person-year; one person living in Denmark for ten years thus counts as ten person-years.

\subsection{The 2013 cohort}

Figure 2 depicts a projection of the population belonging to the 2013 cohort. The bold line shows the total number of people in the cohort. The black line indicates the number of natives, while the grey and dotted lines show the numbers of immigrants and second-generation immigrants from nonWestern countries. Western immigrants and second-generation immigrants are included in the total number, but are not shown separately in the figure.

Figure 2. Numbers of people in the 2013 cohort

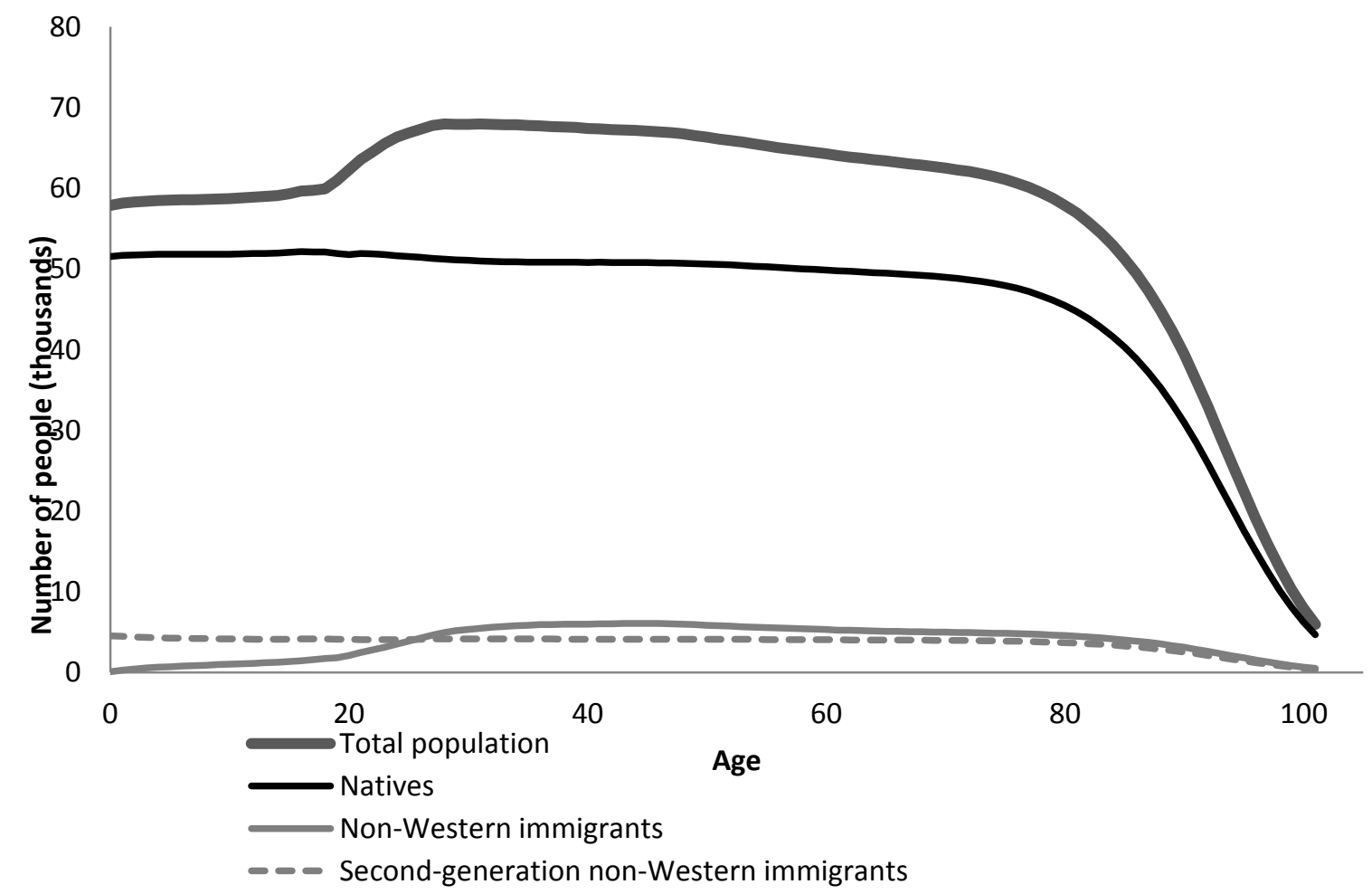

Source: DREAM projection of 2013 
At age zero, the cohort consists of approximately 60,000 people, of whom the majority $(53,000)$ are natives. The cohort includes nearly 6,000 second-generation immigrants, primarily of non-Western origin. The total number in the cohort will rise between the ages of 20 and 30, reaching a high point of almost 70,000. This is due to net immigration of those who were born abroad in the year of 2013. Of the 10,000 immigrants, around half will come from non-Western countries; however, the proportion of non-Western immigrants will increase to around $65 \%$ as the cohort ages, because it is expected that a large proportion of the Western immigrants will leave the country again.

\subsection{Total contributions to public finances by population groups}

In order to calculate the net contribution of a specific population group, public sector revenues and expenditures are distributed between the various population groups. For a detailed description of the principles applied, see Section 3 above. In general terms, the income from taxable individuals comes from the adult population, while expenditures are spread across all age groups.

Figure 3 provides a more detailed picture of how the expenditures are distributed. Total projected expenditures over a lifetime for the 2013 cohort are broken down into expenditure types. As discussed in Section 3, there are some expenses which are fairly evenly spread across the course of a lifetime, since they are for the benefit of all individuals irrespective of gender, age or population group. This applies in particular to expenditure on public goods. Other expenses can be calculated at the individual level, and can therefore be distributed across categories of gender, age and country of origin. These include public services provided to individuals such as education, health and care.

Figure 3. Distribution of public expenditures over the course of a lifetime for the 2013 cohort

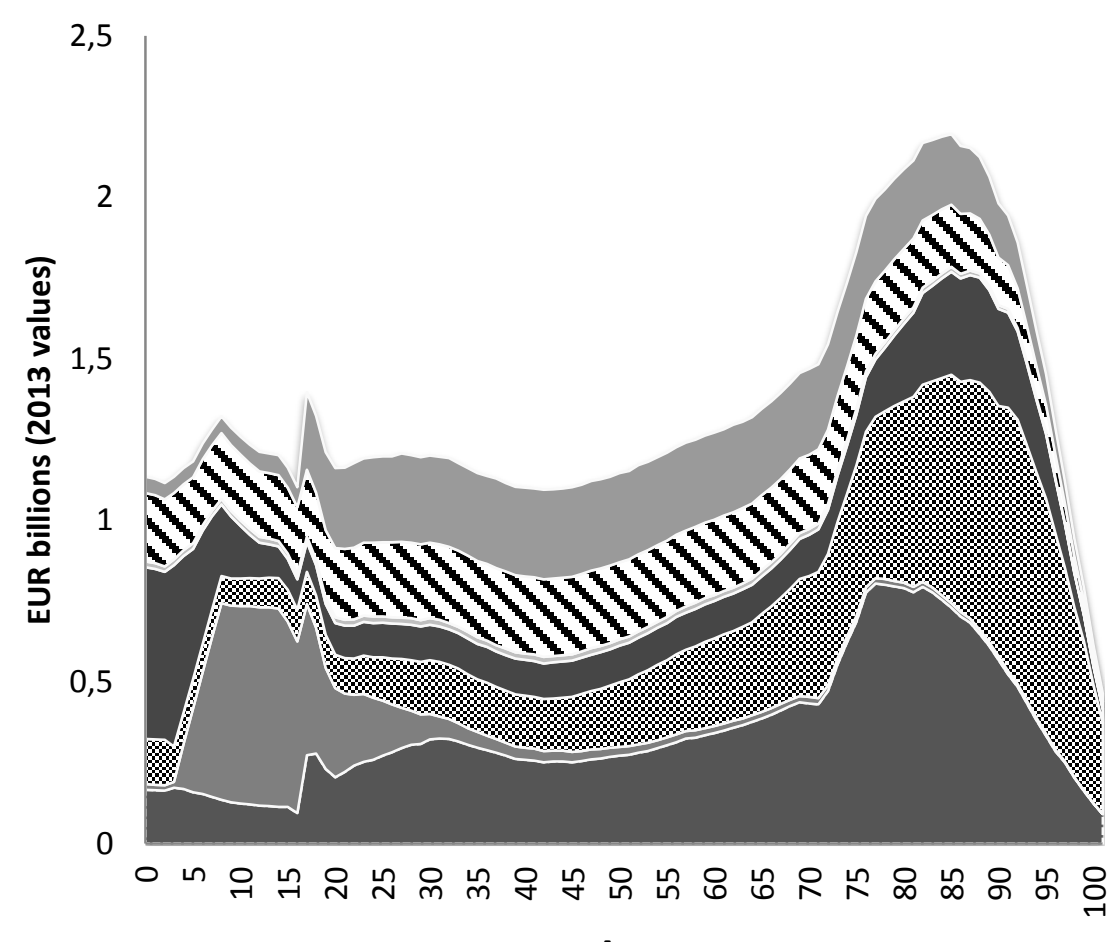

Age
- Other expenditures

Collective expenditures

Other individual expenditures

- Individual social expenditures

Individual expenditures on health

- Individual expenditures on education

Expenditures on transfer incomes

Source: DREAM projection of 2013 
The figure shows that for preschool-age children, expenditures related to individual care make up the largest proportion of spending by the public sector. These expenditures primarily concern day care. From school age onward - not surprisingly - costs regarding education dominate, right through until the age of 20, after which educational costs gradually decline. After this, the cost of transfer incomes gradually becomes more significant, and at the same time individual health expenses begin to rise, though from a fairly low level. The cost of transfer incomes becomes the dominant expenditure item right through until the age of around 80 , after which health expenditure gradually takes over as the major cost as the cohort becomes older and more in need of care. Total costs will peak around the age of 85 , after which they decrease as the cohort dies out.

Total net contributions of the entire 2013 cohort are shown in Figure 4. The net contributions are divided into public revenues and expenditure over the lifetime of an individual. The dotted line in Figure 3 shows total expenses over a lifetime, and thus corresponds to the sum of expenses at each age shown in Figure 3. Over the course of a lifetime, total expenses of the 2013 cohort will remain at a relatively constant level of around EUR 1.3 billion per year (in 2013 values) until around age 50, whereafter the expenditures will begin to rise, as stated above, peaking at around age 85 .

Figure 4. Net contributions of the 2013 cohort

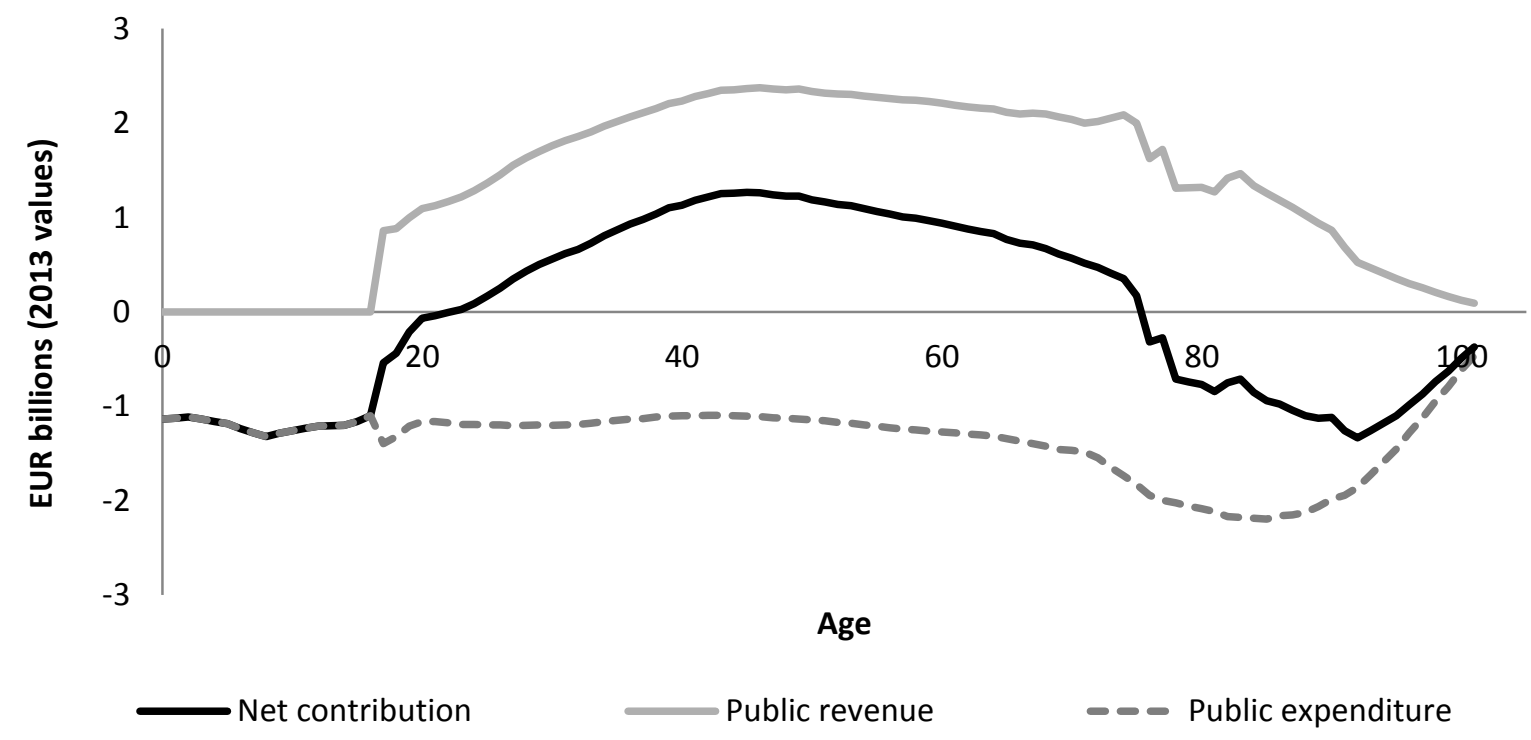

Source: DREAM projection of 2013

The grey line in Figure 4 shows total public revenue, deriving in particular from taxes deducted at source (taxes on wages, transfer incomes and pensions) and from indirect taxes. Individuals under the age of 17 are assumed not to receive taxable income, hence not contributing to the public sector revenue. From the age of 17 and onwards personal income is generated, and thus transfers from households to the public sector will occur. Tax revenues from the 2013 cohort will rise rapidly over the period up until around age 45 , when employment and consequently incomes will reach their 
peak. After this, public revenue declines gradually as pension age approaches. The increase in public revenue predicted around age 80 is due to taxes on old age pension payments.

The black line shows the overall net contribution, and thus represents the difference between public sector revenue and expenditure. Since there is no public revenue before the age of 17 , net contributions track public expenditure up until this point. From then onwards, tax revenue, and thus net contributions, rise - and from age 20 onwards the net contribution will be positive. The increasing revenues and subsequently increasing net contributions will peak at around age 45 , and thereafter will begin to fall, as a consequence of declining tax revenues and because expenditures increase as individuals grow older. The net contribution will become negative once more at around the age of 75 .

As described in Section 2, revenues and expenditures can be assigned to the various population groups. The result of this procedure is shown in Figure 5, which depicts the net contributions of natives, non-Western immigrants, and second-generation immigrants. The total age-dependent net contribution of natives belonging to the 2013 cohort is indicated by a black line, which corresponds very closely to the total net contributions shown in Figure 4 . This is hardly surprising given that natives constitute the majority of the population, as indicated in Figure 2.

Figure 5. Total net contributions of the 2013 cohort, by origin

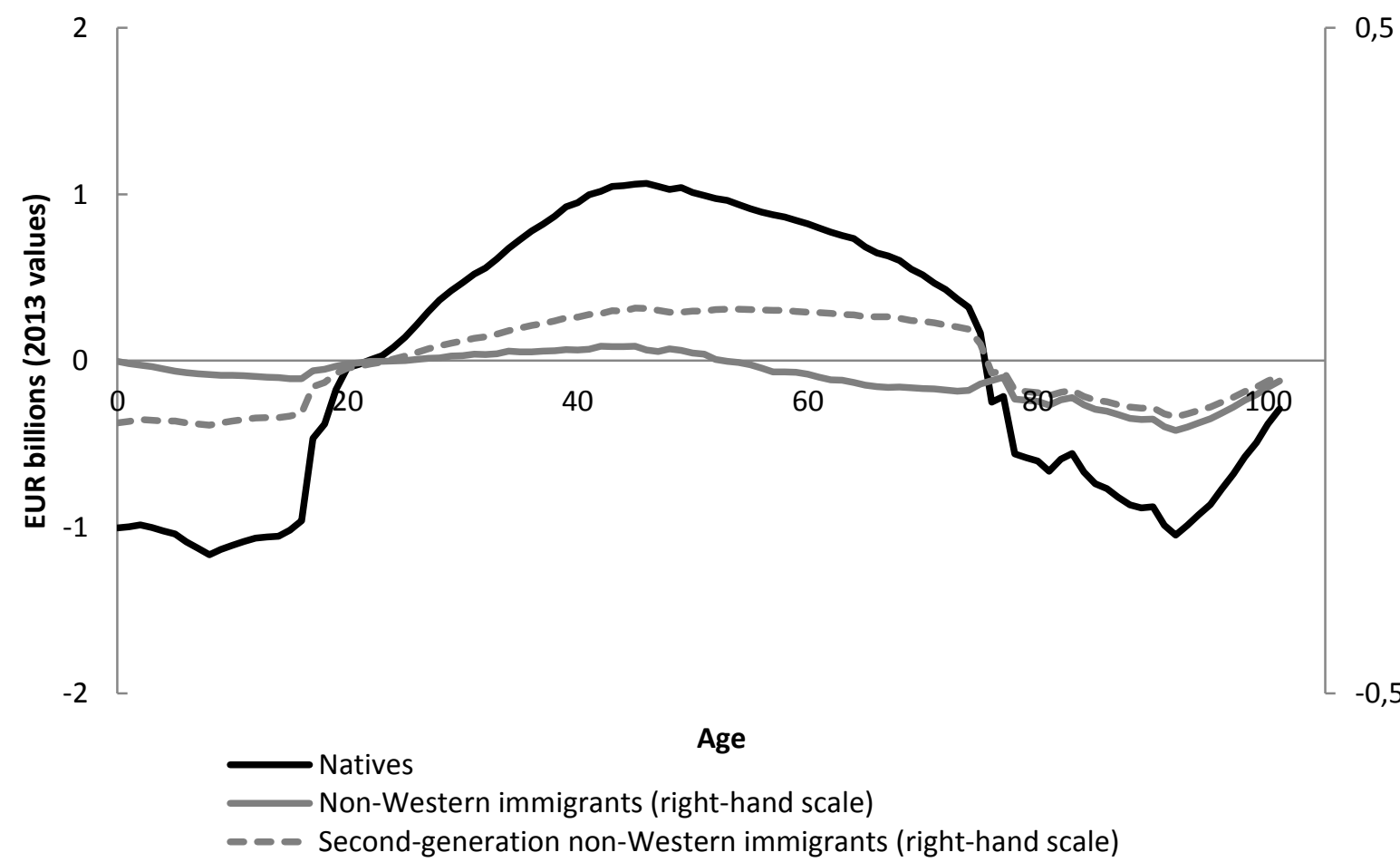

Source: DREAM projection of 2013

The non-Western immigrants and second-generation immigrants constitute small population groups, hence their total net contributions (which are therefore also on a much smaller scale) can be read using the right-hand scale in the figure. It should be noted that it is only between the ages 20 and 50 that first-generation immigrants are projected to make a positive net contribution to public finances, 
while the contributions from natives and second-generation non-Western immigrants are expected to be positive between the ages of 20 and 75 . This is in particular the outcome of the fact that nonWestern immigrants are expected to have significantly lower rates of employment and earnings, resulting in lower tax revenues and higher transfer incomes.

\subsection{Calculating the present value of net contributions by origin}

From the total net contributions for the 2013 cohort, the average net contributions per person-year can be calculated for each population group. This measures the extent to which an average individual from the group in question will contribute (positively or negatively) to the public finances each year during his or her lifetime in Denmark. In practice, this calculation is made by discounting backwards the annual net contributions of the 2013 cohort to the year $2013,{ }^{6}$ and then dividing the amount by the number of person-years.

The number of person-years is calculated as the sum of lifetime years of the members of the 2013 cohort. A native by the age of 80 , who has lived his entire life in Denmark, is thus counted as contributing 80 person-years, whereas an 80 -year-old immigrant who arrived in Denmark at the age of 20 only contributes 60 person-years to the total number of person-years of the cohort. The predicted total number of person-years of the entire 2013 cohort is $5,857,711$. Since the present value of the total net contributions of the 2013 cohort is calculated as being EUR -3.7 billion, the average net contribution per person-year is EUR 637 for each person in the cohort. In other words, a person from the 2013 cohort will benefit on average to the tune of EUR 637 per year from public funds throughout his or her lifetime while residing in Denmark.

The reason that the negative contribution of the 2013 cohort is not expected to give rise to great concern - as mentioned in the introduction, the annual deficit on the primary budget balance is 'only' EUR 0.09 billion per year - is due to the fact that a sustainable fiscal policy does not require that total revenues should cover all spending for all future generations. This in turn is due to that fact that at the time the members of the 2013 cohort were born, there was an existing population, who had already had many of their expenses paid for - day-care, schooling, etc. - and who can therefore be expected to constitute a net surplus for the public purse in the future.

Table 5 shows the net contributions per person-year, distributed by origin. As mentioned previously, the average person in the 2013 cohort will benefit from public spending, with net contributions of EUR -637 per year. Only for people of Western immigrant origin are the figures positive, at EUR 2,546 and EUR 47 for first-generation and second-generation immigrants respectively. The contribution is higher for original immigrants than for second-generation immigrants partly because many firstgeneration immigrants arrive in Denmark after school age, and consequently their day-care and their schooling are not paid for by the Danish exchequer. Immigrants from Western countries also have a

\footnotetext{
${ }^{6}$ The net contribution in 2013 values is discounted by $1.4 \%$ per year, which is the predicted real rate of interest, corrected for growth, to which the public sector is subject.
} 
relatively high propensity to re-emigrate, which results in a reduction in expenses related to old age compared to their native counterparts.

Table 5. Average net contributions per person-year of the 2013 cohort, in 2013 values (EUR).

Population

Whole cohort $-637$

Natives

Immigrants from non-Western countries

$-2,238$

Immigrants from Western countries

2,546

Second-generation immigrants from non-Western countries

$-1,070$

Second-generation immigrants from Western countries

Source: Special run of DREAM

On average, natives generate a net expenditure of EUR 695, while the amount is about $50 \%$ higher for second-generation non-Western immigrants at EUR 1,070. The largest level of expenditure per person-year is associated with first-generation immigrants from non-Western countries. To a large extent, non-Western immigrants will have spent their school years outside Denmark. However, their relationship to the labour market is expected to be much weaker than that of the other population groups, resulting in a significantly higher negative net contribution to the public sector.

\subsection{How much of the net contributions of non-Western immigrants are attributable to refugees?}

When Denmark accepts refugees, it is primarily for humanitarian reasons and a desire to live up to its obligations under the relevant international conventions. For a discussion of whether future labour shortages can be resolved through immigration, it is relevant to distinguish between refugees and other immigrants.

In general, refugees residing in Denmark exhibit a lower rate of labour force participation than other non-Western immigrants. This is partly due to the traumatic experiences that some refugees have gone though, resulting in temporary or permanent damage to their health. It is also to some extent due to the fact that refugees during the last couple of decades have come from the very poorest of the non-Western countries and therefore often have little education and work experience.

In order to calculate the average net contributions among non-refugees, an adjustment has been made whereby the labour market participation rate for refugees is adjusted (primarily upward) to the typical historical level for non-Western immigrants who are not refugees. In other words, the calculation made suggests what the net contribution would have been if refugees participated in the labour market as much as other non-Western immigrants. Since the DREAM model does not distinguish between refugees and non-refugees, changes in the behaviour of refugees can only be targeted by making a proportional change in the rates of all immigrants from non-Western countries. 
This correction is illustrated in Figure 6, where the age-dependent labour force participation rate is depicted for all non-Western immigrants in 2012.

Figure 6. Age-related labour force participation rate in 2012, percent

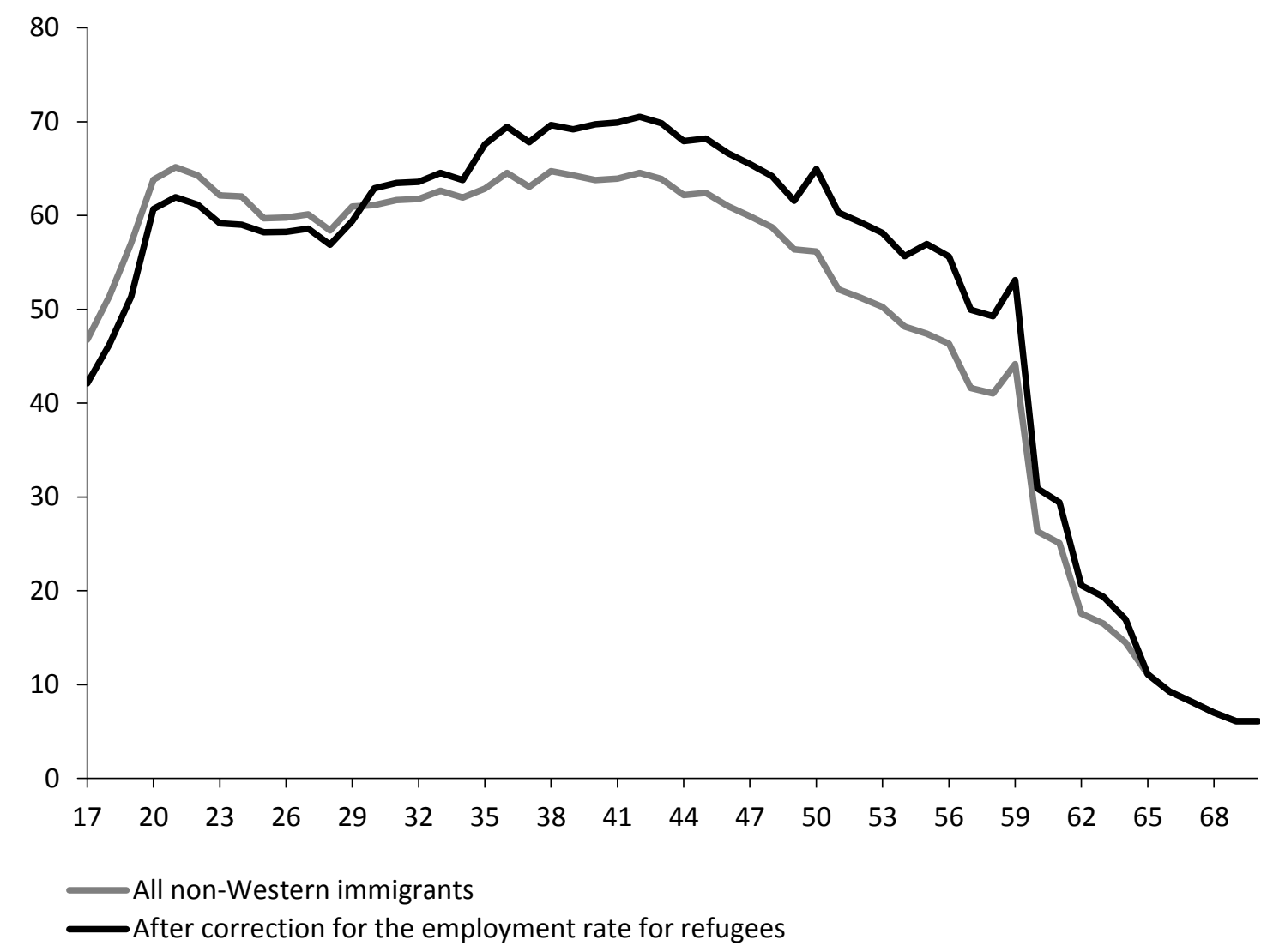

Source: DREAM and own calculations.

As shown, changing the labour force participation rates for refugees leads to a significant rise in the participation rate of non-Western immigrants above the age of 30 . For non-Western immigrants under the age of 30 , the correction results in a fall in the participation rate, since a large fraction of non-Western immigrants in this age group are students; their participation rate is inferior to that of refugees. Overall, the correction for refugees results in a rise in the labour force participation rate, and subsequently an improvement in the net contributions from non-Western immigrants.

If refugees had a participation rate similar to that of other non-Western immigrants, this would positively affect their net contribution (see Table 5a). The table shows that the average net contribution per person-year for non-Western immigrants in the 2013 cohort would rise from EUR $-2,238$ to EUR -1,738 if the participation rate for refugees was improved in the manner described above. The contribution would remain significantly lower than that of natives (EUR -695) and especially than that of Western immigrants (EUR 2,546). The calculation illustrates that there is great potential for improvement through better integration, given that these relatively modest changes regarding labour market participation generate a significant improvement in the net contribution. 
Table 5a. Average net contributions per person-year for the 2013 cohort, in 2013 values (EUR).

Population

Immigrants from non-Western countries

Immigrants from non-Western countries, adjusting average

$-1,738$

labour force participation by simulating improved behaviour of refugees ${ }^{1}$

Note 1: Calculations made with the labour force participation rate of refugees adjusted so that it corresponds to the level of other non-Western immigrants. The calculations were made using an updated version of the DREAM long-term economic projections of 2011.

Source: Special run of DREAM and own calculations

\section{The marginal effect of immigration on fiscal sustainability}

\subsection{The difference between marginal and average calculations}

Until this point, our calculations have been based on the DREAM projections of 2013 and on the distribution among population groups of all public revenues and expenditures, including the costs of fixed public goods as described in Section 3. Overall, this has shown us to what extent an average person from any given group will make a net positive or negative contribution to the public purse.

However, it can be argued that not all public expenditures should be considered as responding to changes in the size of the population. If the costs of defence, administration and roads do not increase with a marginal increase in the size of the population, or if there are economies of scale, then the additional expenditures resulting from the admission of more members of the population will be below the overall average cost. In principle, the same could apply to state revenues; but as we have noted earlier, revenues of the public sector largely stems from taxes paid by individuals, so in fact the income side of the public account is more closely related to the size of the population.

When the level of immigration is under discussion, it is in fact the question of marginal changes to expenditure that should be considered. In this section, therefore, we aim to perform marginal calculations by keeping the cost of providing the fixed public goods constant, while at the same time making changes to the possible annual inflow of immigrants.

\subsection{Predicted level of immigration (baseline projection) and a reduction by 5,000 non- Western immigrants per year}

The population projection by Statistics Denmark and DREAM is termed the 'baseline projection' below (see DREAM, 2013a and 2013b). The deviation from this baseline projection used in the following consists of an assumed reduction of 5,000 persons in the annual number of non-Western immigrants from 2013 onwards. Adjustments of this order are often used when making projections in DREAM; there is no other significance in the choice of this particular figure of 5,000, and the results are more or less scalable. The change is shown in Figure 7, where the projected reductions in size of the population up until 2050 are shown by origin. 
Overall, the alternative projection leads to a reduction in the Danish population by 152,000 individuals in the year 2050 relative to the baseline projection. The majority of the reduction (around $98,000)$ is in the size of the non-Western immigrant group, and thus represents a direct effect of the reduction in immigration after taking into account expected re-migration and mortality.

The size of the population of second-generation non-Western immigrants is of course affected as well, since there will be fewer births when there are fewer women of reproductive age. In 2050, therefore, there would be 37,000 fewer non-Western second-generation immigrants. Some nonWestern immigrants to Denmark marry Danish nationals born in Denmark. According to the Statistics Denmark's system of classification, the children of such individuals are considered as being of Danish origin. This means that a reduction in the number of non-Western immigrants also leads to a reduction in the number of natives in the population by approximately 17,000 in 2050.

Figure 7. Changes in the size of the various population groups relative to the baseline projection, in numbers of individuals.

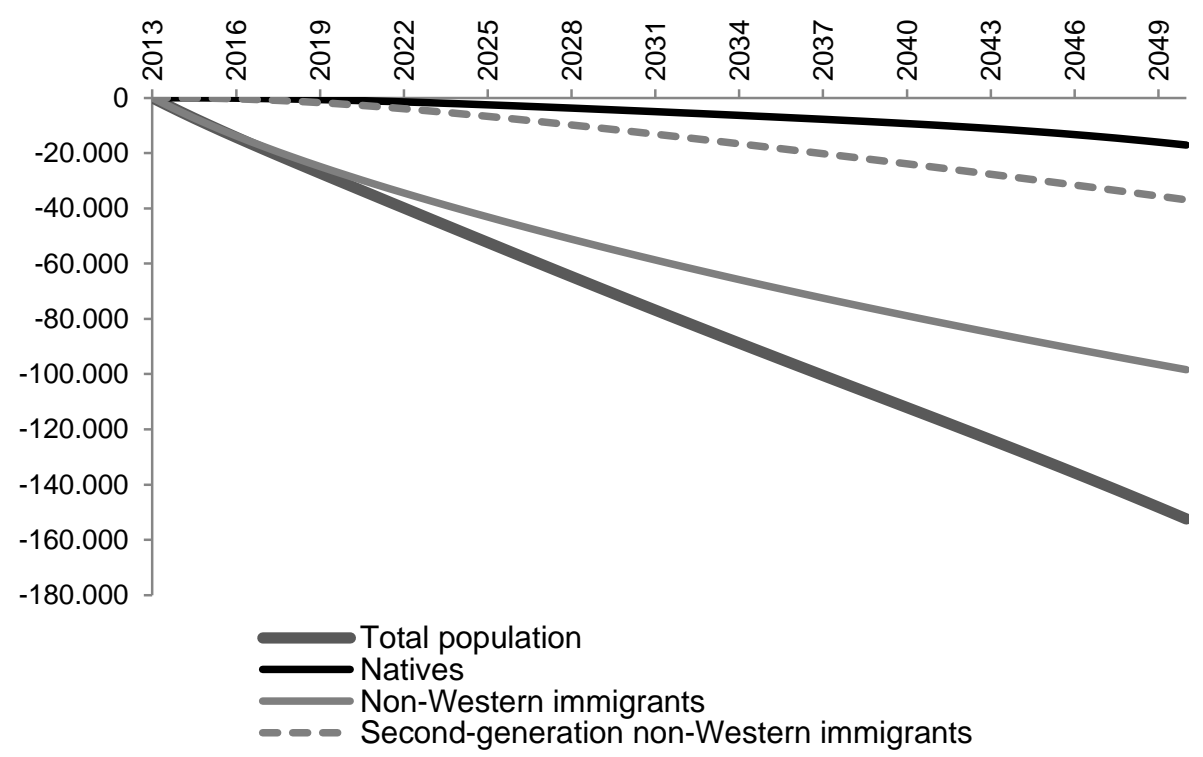

Source: Special run of DREAM

When the population is reduced in size, the workforce also becomes smaller - but the amount by which the workforce is reduced, and the time of the reduction, depends on the composition of the various population groups and their expected level of participation in the labour market.

The calculations in this case show an expected reduction in the workforce by 62,000 in $2050-a$ reduction which appears relatively modest in comparison with the reduction in the whole population by 152,000 .

There would be almost 50,000 fewer non-Western immigrants in the workforce by 2050 , while the numbers of second-generation non-Western immigrants and natives would be reduced by around 10,000 and 3,500 respectively. The reduction in numbers of natives and second-generation 
immigrants in the workforce would begin to take effect from 2035, when these people would be old enough to enter the work force.

Figure 8. Change in the size of the workforce relative to the baseline projection for various population groups, in numbers of individuals.

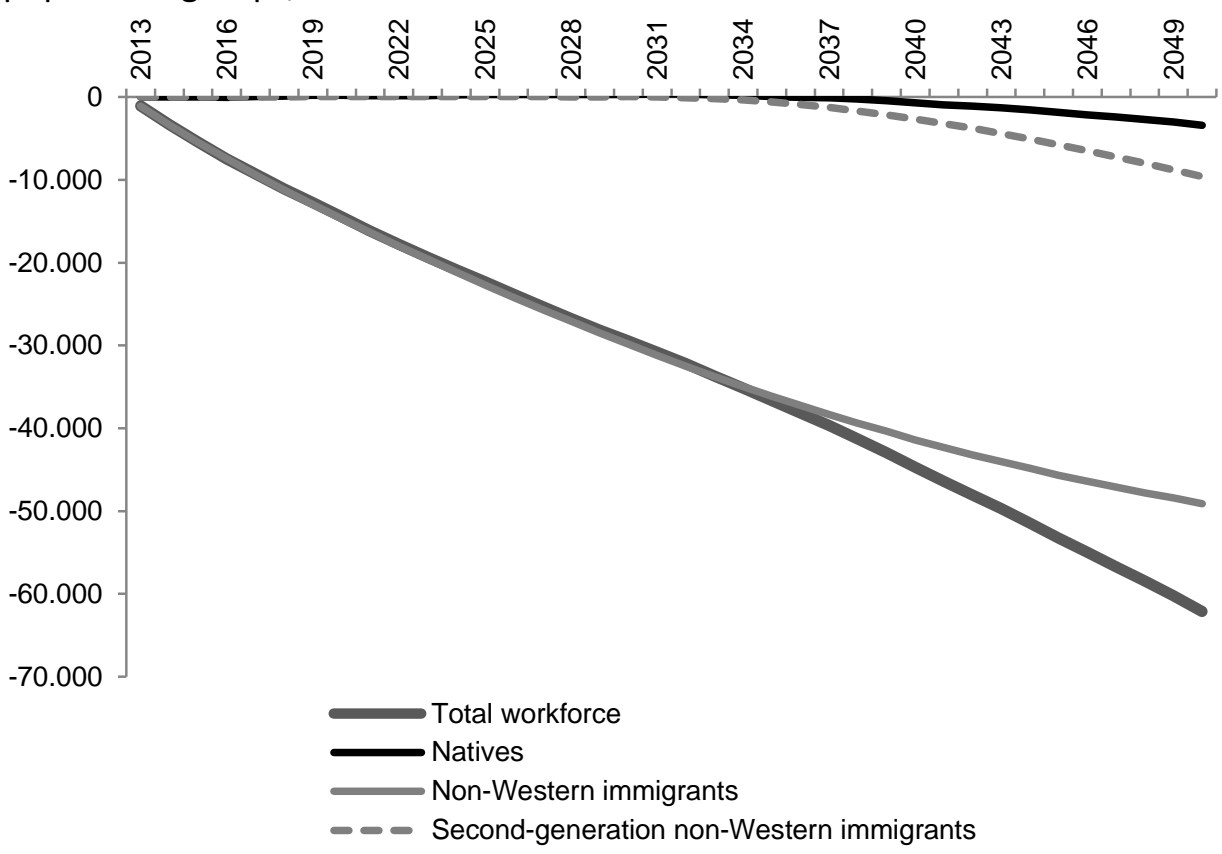

Source: Special run of DREAM

The changes in the size of the workforce are shown until 2050, but the reduction continues in subsequent years and is taken into account when assessing the fiscal consequences of the reduction in the immigration level (see below).

\subsection{The effect on fiscal sustainability of changing the immigration inflow}

When the workforce is reduced, it leads to a reduction in the number of people in employment as well. The aforementioned fall in annual immigration would reduce employment by $2 \%$ and GDP by $1.4 \%$ in the year 2050 relative to the baseline projection. GDP per capita would thus increase from EUR 41,830 to EUR 42,440 , or $1.4 \%$. Nominal wages would increase by $0.5 \%$ and real wages by $0.4 \%$.

As discussed previously, expenditure on fixed public goods is assumed to be unaltered, while public expenditure related to individuals would be reduced by $2.1 \%$, producing an overall reduction of $1.6 \%$ in total public spending in 2050 relative to the baseline projection.

The reduced level of economic activity would lead to a reduction in corporate investment and induce companies to raise prices in order to compensate for the lower production level. This in turn would lead to a reduction in exports in 2050 by approximately $1 \%$. However, due to lower production, lower wages and hence lower demand for foreign goods and production inputs by companies and 
households, imports would also fall. The reduction in imports would be greater than the reduction in exports; hence, net exports would rise by $1.6 \%$ in 2050 .

In total, the calculations show that the surplus in the public budget would rise (relative to GDP) in comparison with the baseline projection. This is basically because the rate of labour market participation and the productivity of non-Western immigrants are too low to compensate for the increased public consumption that they generate.

Table 6 shows the annual changes in both the primary budget balance in EUR and the sustainability indicator. The starting point is a calculation based on DREAM's baseline projection, in which the sustainability indicator is $-0.04 \%$ of GDP and thus practically consistent with fiscal sustainability. This corresponds to a permanent annual deficit in public finances of EUR 0.09 billion.

If contributions are distributed according to contributors' origins, as outlined in Section 2.2, the annual contribution of natives is EUR 0.2 billion, while Western immigrants and Western secondgeneration immigrants contribute EUR 1 billion and EUR 0.08 billion respectively. For non-Western immigrants the net contribution is negative at EUR -1.3 billion, while for second-generation nonWestern immigrants it is EUR -0.05 billion.

Table 6. Permanent changes in the primary balance in EUR billions in 2013 (2012 values) and in the sustainability indicator (SI), distributed according to origin, as percentages of GDP

\begin{tabular}{|c|c|c|c|c|c|c|c|}
\hline & \multicolumn{2}{|l|}{ Non-Western } & \multicolumn{2}{|l|}{ Western } & \multirow[t]{2}{*}{ Natives } & \multicolumn{2}{|c|}{ Total population } \\
\hline & Immigrants & $\begin{array}{l}\text { Second- } \\
\text { generation } \\
\text { immigrants }\end{array}$ & Immigrants & $\begin{array}{l}\text { Second- } \\
\text { generation } \\
\text { immigrants }\end{array}$ & & & \\
\hline & --------------. & -------------- & - EUR billions & --------------- & --- & EUR bn & $\mathrm{SI}^{1}$ \\
\hline $\begin{array}{l}\text { Baseline } \\
\text { projection }^{2}\end{array}$ & -1.30 & -0.05 & 0.97 & 0.08 & 0.21 & -0.09 & -0.04 \\
\hline $\begin{array}{l}5,000 \text { fewer non- } \\
\text { Western } \\
\text { immigrants per } \\
\text { year }\end{array}$ & -1.07 & -0.04 & 0.99 & 0.08 & 0.22 & 0.19 & 0.08 \\
\hline Difference & 0.23 & 0.01 & 0.03 & 0.00 & 0.01 & 0.28 & 0.12 \\
\hline
\end{tabular}

Notes: 1) Sustainability indicator. 2) The baseline projection is from DREAM's long-term economic projection of 2013.

Source: Special run of DREAM

The effects of an annual downward adjustment in immigration by 5,000 non-Western immigrants are shown in Table 6 . The sustainability indicator becomes positive at $0.08 \%$ of GDP, which corresponds to an annual improvement of the primary balance of EUR 0.2 billion. This means that the sustainability indicator is improved by 0.12 percentage points, and the primary balance by EUR 0.28 billion annually compared to the baseline scenario. A small part of the improvement (EUR 0.04 billion) is attributable to effects deriving from natives and individuals of Western origins and for second-generation non-Western immigrants (EUR 0.01 billion). However, the largest element of the contribution comes from an improvement by EUR 0.2 billion from the non-Western immigrant group. 
The improvement of the sustainability indicator by 0.12 given a reduction in immigration of 5,000 non-Western immigrants yearly is a somewhat lower effect than the 0.49 estimated by Schou (2006) for immigrants from less developed countries. This difference can to some extent be explained by differences in set-up (definition of immigrant-groups and reduction in inflow) and the fact that we conduct a marginal experiment, where public goods are assumed to be fixed. Other important explanations are that labour force participation rates among non-Western immigrants have improved since the 2001 version of DREAM used by Schou and that the general sustainability of the public finances has improved (from $-2,9 \%$ to $-0,04 \%$ of GDP), primary due to political reforms increasing the projected size of the future labour force in Denmark.

\section{Summary and conclusions}

In this paper, we ask to what extent the different population groups in Denmark contribute to public finances today, and are expected to do so in the future. We focus on three different computations. We first compute the annual net contributions to the public sector from each population group in 2014 and in 2050. Next, we compute the present values of lifetime net contributions for the 2013 cohort. The calculation is performed for the entire population and for each of the population groups examined. These computations allocate the costs of fixed public goods equally across all individuals, meaning that immigrants are assumed to be paying the average costs of fixed public goods. Finally, we consider how changes in the annual immigration inflow from poor countries would affect public finances under the assumption that the costs of providing fixed public goods to immigrants are zero. These figures can therefore be interpreted as the marginal cost of immigration from poor countries.

The expected fiscal impact of immigration from non-Western countries to Denmark will amount to a EUR 2.2 billion deficit for 2014. Furthermore, despite a clear improvement in integration over the past 15-20 years and a strong shift in the pattern of immigration towards immigration for work and study purposes, there is still no prospect of non-Western immigration generating a surplus for the public purse. Even in 35 years' time, non-Western immigration will still not be making a positive net contribution to solving the problems of financing the Danish welfare state - problems which will exist in part as a consequence of the ageing population, with fewer people of working age. On the contrary, immigration from non-Western countries will exacerbate the financial problems facing the welfare state by an additional EUR 0.8 billion, unless integration is further improved. The reason that we should still expect a deficit in 2050 lies in a weak labour market performance, the fact that people with low education including many non-Western immigrants tend to retire early, and the provisions of the universal Danish pension system.

Immigration from Western countries will have the opposite effect, generating a net surplus of EUR 0.5 billion in 2014. In the future, immigration from Western countries will be an even more important source of financing for the welfare state, with a net contribution reaching EUR 1.2 billion by 2050 - that is, assuming that patterns of immigration and integration continue as at present.

As expected, net payments from the public purse to individuals with non-Western backgrounds are found to be distributed very differently to first-generation and to second-generation immigrants, and this will also be the case in 2050. Today, second-generation non-Western immigrants account for 
EUR 1.7 billion in net expenditure from the Danish public purse, and first-generation immigrants from non-Western countries account for net spending of EUR 0.55 billion. The latter group has a low rate of employment, while the former consists of people who are better integrated, but who are still young and frequently in education.

If we look forward in time by half a generation to 2050 , the first generation of non-Western immigrants will have begun to leave the labour market and the annual net deficit for this group will have climbed to EUR 1.6 billion. In contrast, the second-generation immigrants will have reached adulthood and become active in the labour market. Their present deficit in relation to public finances will have been transformed into a surplus of EUR 0.83 billion, so that combined, the first and second generations of non-Western immigrants will produce a net deficit of EUR 0.80 billion, down from 2.2 billion in 2014. This improvement reflects the better integration on average over both the first and the second generation. The improvement is driven almost entirely by higher employment among the second generation, which is strong enough to dominate the lower average employment among all first generation immigrants, young and old, because of retirement.

These calculations illustrate that a welfare state such as that of Denmark - with its many universal and relatively generous welfare programmes financed largely by taxes on earned income - needs to see a surplus of incoming payments over outgoing payments from immigrants of the first generation if it wishes to obtain a positive contribution to its long-term financing through immigration. If firstgeneration immigrants produce a deficit, or only break even, then succeeding generations will at best make net contributions of the same order as natives of the country in question; and in the case of Denmark, that means that their contribution to public finances will at best be in balance. Any surplus must thus be existent for immigrants of the first generation, if the overall accounting is to show a financial benefit from immigration.

The analysis also shows that second-generation non-Western immigrants have come a long way in comparison with their parents in terms of their financial relationship with the welfare state. Even though the Danish public sector has contributed to the children's upbringing, but only to a limited extent to that of some of the parents, second-generation non-Western immigrants are expected to draw far less on state finances than their parents. This becomes clear when we look at the expected average lifetime net contributions for the various groups.

The average net contribution per person to the public purse for each year that an individual is in Denmark, as calculated in 2013 values, is EUR - 695 for natives and EUR -1,070 for second-generation non-Western immigrants; the expenditure from the public purse per person-year for secondgeneration non-Western immigrants is thus $50 \%$ above the level of natives. In comparison, the firstgeneration non-Western immigrants make an average annual net contribution of EUR -2,238 or three times the level of natives. By way of comparison, Western immigrants on average make an annual net contribution to public funds of EUR 2,546, while second-generation Western immigrants make a net contribution of only EUR 47 per year. As expected, the figure for second-generation immigrants is much lower, reflecting the facts that they, unlike their parents, have drawn on state funds throughout their upbringing in Denmark, and that first generation Western immigrants are well integrated into Danish society. 
The modest average net contribution of second-generation Western immigrants of EUR 47 annually in 2013 values should be compared with contributions of EUR -695 for natives and EUR -1,070 for second-generation non-Western immigrants, which are the two other groups to have been born and brought up in Denmark. It is noticeable that the second-generation non-Western immigrants do much better than their parents' generation, despite the fact that they, unlike their parents, have made use of public funds throughout their upbringing. Thus, non-Western second-generation immigrants contribute more than their parents to the state finances, while Western secondgeneration immigrants contribute less than their parents, which is the more expected pattern.

As mentioned above, these computations assume that immigrants are allocated the average per capita costs of fixed public goods. We have also considered the case where the marginal costs of providing fixed public goods to immigrants are assumed to be zero, and this is taken up in the discussion of the last issue considered in the paper, which was the question of how changes in immigration policy would affect public finances. Specifically, we analysed the effect of 5,000 nonWestern immigrants annually on public finances. The effect can be found by comparing the fiscal sustainability in two projections that differ only in one projection assuming an inflow of 5,000 more non-Western immigrants than the other. In the years 2008-12, around 14,500 non-Western immigrants arrived in Denmark each year. Some of them will leave again, but the majority settle. We showed in the paper that the last 5,000 people in the forecast annual immigration will create an additional deficit for the public finances of, on average, EUR 0.3 billion per year, which is equivalent to a decrease in the fiscal sustainability indicator of 0.12 percentage points in relation to GDP. Taking out 5,000 immigrants annually from the calculations results in a sustainability indicator of $0.08 \%$ of GDP, while the indicator is $-0.04 \%$ of GDP if the 5,000 non-Western immigrants are included in the calculation.

These figures should be interpreted as the marginal public cost of immigration, in that they only take into account spending and income associated with individuals (unemployment benefit, visits to the doctor, tax, etc.) and not the costs of providing fixed public goods (armed forces, construction of roads and bridges, central administration, etc.). Such marginal costs are those that are relevant for the political discussion of whether to have a higher or lower annual level of immigration in the future.

Integration into the labour market is of great significance for the fiscal effects of immigration. The average net contribution to public finances during years lived in Denmark for non-Western immigrants is EUR -2,238 yearly, and this is very largely attributable to low levels of employment for this group - levels which are low in any case during working-age years and low because of early retirement on public pension schemes. If Denmark could succeed in improving integration to such an extent that, for example, refugees improved their level of attachment to the labour market to the same level as that of other non-Western immigrants, the average net contribution of the nonWestern group to public finances would rise (i.e. be less negative) to EUR -1,738 annually, which would represent an improvement by $22 \%$. This would have at least as great an effect on the fiscal sustainability as reducing the number of non-Western immigrants by 5,000 . 
Let us return to our initial question. Is it possible for a country like Denmark to use immigration to strengthen its financial sustainability? The answer is yes - provided that the immigrants have good prospects for employment in Denmark and that they remain active on the labour market for a long time. Western immigrants seem to have a positive impact on the economy, while non-Western immigrants have a negative fiscal impact. The negative effect of immigration from poor countries is the result of low rates of employment while the immigrants are in the labour force, and of early retirement from the labour market. Denmark is different from other countries both because of its welfare model and because of its history of attracting many immigrants with weak labour market prospects. The results reported here may even be optimistic with respect to labour market performance, because the forecast made is based on the year 2008, when the level of employment among immigrants in Denmark was at its highest for decades. 


\section{References}

Borjas, G. J. 1990. Friends and strangers. The impact of immigrants on the US economy. New York: Basic Books.

Danmarks Statistik. 2013. Indvandrere i Danmark 2013. Copenhagen.

Dustmann, Christian and Tommaso Frattini. 2013. The fiscal effects of immigration to the UK. The economic journal vol. 124, no. 580, pp. F593-F643.

DREAM. 2011. Langsigtet økonomisk fremskrivning 2011. Copenhagen.

DREAM. 2013a. Danmarks fremtidige befolkning - befolkningsfremskrivningen 2013. Copenhagen.

DREAM. 2013b. Langsigtet økonomisk fremskrivning 2013. Copenhagen.

Gerdes, Christer, Marie Louise Schultz-Nielsen and Eskil Wadensjö. 2011. The significance of immigration for public finances in Denmark. Rockwool Foundation Research Unit study paper no. 35. Odense: University Press of Southern Denmark.

Hinte, Holger and Klaus F. Zimmermann. 2014. Does the Calculation Hold? The Fiscal Balance of Migration to Denmark and Germany. IZA Policy Paper, no. 87.

Ruist, Joakim. 2014. Free immigration and welfare access: The Swedish experience. Fiscal studies, vol. 35, pp.19-39.

Schou, Poul. 2006. Immigration, integration and fiscal sustainability. Journal of population economics, vol. 19 , no. 4, pp. 671-689.

Tranæs, Torben. 2012. Immigration laws affect integration - The politicians decide how. International Organization for Migration.

Velfærdskommissionen. 2004. Fremtidens velfærd kommer ikke af sig selv. Copenhagen

Wadensjö, Eskil. 2000. Immigration, the labour market, and public finances in Denmark. Swedish economic policy review, vol. 7, pp. 59-84.

Wadensjö, Eskil. 2007. Immigration and the net transfers within the public sector in Denmark. European journal of political economy, vol. 23, no. 2, pp. 472-85.

Wadensjö, Eskil and Christer Gerdes. 2004. Immigrants and the public sector in Denmark and Germany, in Torben Tranæs and Klaus Zimmerman (eds), Migrants, work and the welfare state. Odense: University Press of Southern Denmark. 